\title{
Peningkatan Kemampuan Koneksi Matematis Siswa melalui Pendekatan Open-Ended pada Siswa Sekolah Menengah Pertama
}

\author{
Roslian Lubis $^{1 *}$, Toharuddin Harahap ${ }^{2}$, Marzuki Ahmad ${ }^{3}$ \\ 1,2,3 Institut Pendidikan Tapanuli Selatan, Padangsidimpuan, Sumatera Utara 22716, Indonesia \\ Pengiriman: 30 Juli 2019; Diterima: 23 Oktober 2019; Publikasi: 30 Oktober 2019 \\ DOI: https://doi.org/10.31629/jg.v4i2.1367
}

\begin{abstract}
Abstrak
Rendahnya Kemampuan Koneksi Matematis (KKnM) siswa merupakan permasalahan utama penelitian. Permasalahan di lapangan siswa kurang mampu mengaitkan konsep/ide matematika dalam pemecahan masalah matematis. Dengan demikian perlu suatu pendekatan pembelajaran yang memacu siswa untuk menyelesaikan masalah dengan fleksibel yaitu pembelajaran dengan pendekatan open-ended. Tujuan penelitian ini adalah untuk mengetahui peningkatan KKnM siswa SMP melalui pendekatan open-ended. Untuk mencapai tujuan tersebut dilakukan penelitian eksperimen semu dengan rancangan Nonequivalent Control Group Design. Populasi penelitian adalah siswa kelas VII SMP Negeri 5 Padangsidimpuan. Sampel yang dipilih adalah kelas VII-5 sebagai kelas eksperimen dan siswa kelas VII-6 sebagai kelas kontrol. Penelitian yang dilakukan menunjukkan hasil melalui uji independen sampel t-tes diperoleh signifikansi hasil pretest dan posttest sebesar 0,004 yang berarti terdapat perbedaan rata-tara antara $\mathrm{KKnM}$ siswa kelas eksperimen dengan kelas kontrol. Selanjutnya melalui uji $N$-gain diperoleh nilai rata-tara $N$-gain kelas eksperimen sebesar 0,48 yang berarti nilai peningkatan berada pada kategori sedang dan pada kelas kontrol diperoleh nilai $\mathrm{N}$-gain sebasar 0,28 yang berarti berada pada kategori rendah. Dengan demikian disimpulkan bahwa KKnM siswa melalui pendekatan open-ended berbeda secara signifikan dengan KKnM siswa dengan pendekatan konvensional dan $\mathrm{KKnM}$ siswa yang diberi pembelajaran dengan pendekatan open-ended lebih baik dari pada KKnM siswa dengan pendekatan konvensional.
\end{abstract}

Kata kunci: koneksi matematis; pendekatan pembelajaran; open-ended

\begin{abstract}
The low Mathematical Connection Ability (MCA) of students is the main problem of research. Problems in the field of students are less able to connect mathematical concepts/ideas in mathematical problem solving. Thus a learning approach is needed that spurs students to solve problems with flexibility, namely learning with an open-ended approach. The purpose of this study was to determine the improvement of MCA of junior high school students through an open-ended approach. To achieve this goal, a quasi-experimental study was conducted with a pretest posttest control group design. The study population was seventh grade students of SMP Negeri 5 Padangsidimpuan . Through cluster random sampling selected students of class VII-5 as the experimental class and students of class VII-6 as the control class. The research conducted shows the results through the Independent Samples Test obtained the significance of the results of the pretest and posttest of 0.004 , which means that there are differences between the MCA students in the experimental class and the control class. Furthermore, through the N-gain test the average $\mathrm{N}$-gain class experiment value was 0.48 , which means that the value of improvement was in the medium category and in the control class the $\mathrm{N}$-gain value was 0.28 which means it was in the low category. Thus it was concluded that the MCA students through the open-ended approach differed significantly from the MCA students with the
\end{abstract}




\section{JURNAL GANTANG. Oktober; IV(2): 121 - 132 \\ p-ISSN. 2503-0671 \\ e-ISSN. 2548-5547}

conventional approach and the MCA students who were given the open-ended learning approach better than the MCA students with the conventional approach.

Keywords: mathematical connection; learning approach; open-ended

\section{Pendahuluan}

Matematika merupakan ilmu pengetahuan yang dipelajari pada berbagai jenjang pendidikan. Permendikbud Nomor 58 Tahun 2014 (Mendikbud, 2014) pada lampirannya mengungkapkan dalam melaksanakan pembelajaran peserta didik seharusnya dapat merasakan kegunaan dari belajar matematika. Untuk dapat merasakan kegunaan matematika perlu menghubungkan atau mengkaitkan konsep-konsep antar matematika dan menghubungkannya dengan bidang lain yang pada akhirnya dapat berguna dan dibermaknakan dalam kehidupan sehari-hari. National Council of Teachers of Matematics (NCTM, 2000) mengungkapkan terdapat lima standar proses dalam pembelajaran matematika salah satunya adalah belajar untuk menhubungkan atau mengaitkan ide atau konsep matematika (mathematical connections).

Koneksi matematis bertujuan untuk membantu siswa melihat bahwa ide-ide matematika memiliki hubungan antara satu dengan lainnya. Sebagimana yang dikemukakan Puteri \& Riwayati (2017) bahwa siswa yang memiliki kemampuan koneksi matematis (KKnM) akan lebih mampu memahami materi secara keseluruhan dan ingatannya bertahan lama dan akan mampu melihat hubungan antar topik dalam matematika, hubungan antar topik di luar matematika maupun hubungan antar topik matematika dengan kehidupan sehari-hari. Melalui koneksi matematis yang baik siswa akan memahami hubungan internal matematika yang meliputi hubungan yang terdapat antar konsep/prinsip matematika itu sendiri dan hubungan eksternal meliputi hubungan antara konsep/ prinsip matematika dengan konsep/prinsip mata pelajaran lain dan kehidupan sehari-hari.

The Oxford English Dictionary mengungkapkan bahwa koneksi merupakan hubungan keberadaan seseorang, hal, atau ide terkait dengan sesuatu yang lain, sehingga pada akhirnya koneksi matematis dinyatakan sebagai hubungan antara ide matematika yang terkait atau berhubungan dengan ide matematika yang lainnya (Tasni \& Susanti, 2017). Pengertian ini mengandung makna bahwa koneksi matematis memungkinkan siswa untuk memandang bagaimana sebuah konsep matematika dapat membantunya memahami konsep-konsep lainnya baik dalam mata pelajaran matatematika itu sendiri maupun pelajaran diluar matematika.

Selanjutnya Pitriani \& Afriansyah (2016) juga mengungkapkan koneksi matematika merupakan keterkaitan antara matematika dengan topik matematika, matematika dengan disiplin ilmu lain di luar matematika dan matematika dengan dunia nyata atau dalam kehidupan seharihari. Dengan adanya kemampuan koneksi maka konsep matematika dapat dibangun melalui penghubungan ide, konsep atau prosedur dalam matematika menjadi suatu temuan baru yang dapat lebih dipahami. Ketika ide-ide matematika saling dihubungkan maka prinsip utama dari materi yang dipelajari akan dapat diperoleh dan dapat dipahami secara mendalam dan dapat diterapkan dalam berbagai soal pemecahan masalah matematika. Dengan demikian disimpulkan bahwa koneksi matematis merupakan hubungan antara ide matematika, dan antara satu kesatuan matematika dengan disiplin ilmu lainnya.

Indikator kemampuan koneksi matematis menurut NCTM (2000) meliputi : 1) Mengenal dan menggunakan hubungan/ keterkaitan yang terdapat pada ide-ide matematika; 2) Memahami hubungan antara ide-ide matematika dan membangun hubungkan ide matematika tersebut satu sama lainnya; 3) Menerapkan ide matematika dalam konteks/ situasi di luar matematika. 
Selanjutnya Sumarmo (2014) mengungkapkan bahwa koneksi matematis merupakan kemampuan hard skill matematika level tinggi atau level rendah yang tergantung kepada tingkat kesulitan hubungan yang disajikan, dan koneksi matematis tersebut dapat diukur melalui indikator: 1) mencari hubungan antar konsep, prosedur, dan topik pelajaran matematika; 2) mencari hubungan antara topik pelajaran matematika dengan topik pelajaran bidang studi lain ; 3) menentukan representasi ekuivalen suatu konsep matematika.

Selanjutnya Putra \& Syarifuddin (2019) mengungkapkan bahwa untuk mengukur KKnM dapat digunakan tolak ukur yaitu mengetahui hubungan dari ide-ide matematika, menerapkan atau mengaplikasikan hubungan dari ide-ide matematika, memahami hubungan dari ide-ide matematika, mengetahui hubungan dari ide-ide bidang matematika dengan ide-ide pada bidang ilmu lain, menerapkan hubungan dari bidang matematika dengan bidang ilmu lain. Memperhatikan uraian tentang indikator $\mathrm{KKnM}$ maka disimpulkan indikator $\mathrm{KKnM}$ meliputi memahami dan menerapkan hubungan antar berbagai konsep atau materi matematika, menerapakan konsep atau materi matematika dalam suatu permasalahan dan menerapkan konsep atau materi matematika dalam permasalahan sehari-hari.

Dewasa ini pembelajaran yang terjadi kurang memperhatikan kemampuan bermatematika siswa. Pembelajaran yang terjadi cenderung bersifat transfer ilmu pengetahuan dan hapalan pada suatu materi tertentu. Hal ini membuat siswa kurang mamahami materi yang dipelajari, ingatan siswa terhadap materi pembelajaran bersifat sementara, serta ilmu yang diperoleh kurang dapat dikembangkan siswa. Kenyataan di lapangan, hasil analisa PISA (Programme for International Students Assesment) 2009 capaian prestasi matematika siswa kelas VII SMP kita berada pada peringkat 34 dari 41 Negara, Sementara pada PISA 2012 berada pada peringkat 64 dari 65 Negara dan PISA 2015 berada pada peringkat 63 dari 70 Negara (Hadi, 2017). Berdasarkan capaian peringkat tersebut negara Indonesia berada pada peringkat terendah dalam perolehan nilai matematika. Salah satu penyebab rendahnya perolehan nilai matematika tersebut adalah karena rendahnya kemampuan siswa dalam mengkoneksikan berbagai konsep matematika.

Selanjutnya berbagai penelitian mengungkapkan bahwa kemampuan bermatematika khususnnya KKnM siswa masih rendah. Penelitian Sugiman (2008) mengungkapkan bahwa penguasaan untuk setiap aspek koneksi meliputi aspek koneksi inter topik matematika $63 \%$, antar topik matematika $41 \%$, matematika dengan pelajaran lain $56 \%$, dan matematika dengan kehidupan 55\%. Secara keseluruhan capaian KKnM siswa adalah mencapai rata-rata $53,8 \%$ tergolong dalam capaian rendah.

Sementara itu, penelitian Purwaningrum (2016) menunjukkan bahwa siswa SD memiliki $\mathrm{KKnM}$ yang rendah dan para siswa beranggapan bahwa belajar matematika sangat membosankan karena termasuk pelajaran yang susah. Selain itu diungkapkan juga bahwa padangan para siswa terhadap materi-materi dalam pelajaran matematika antara satu dengan yang lainya tidak berhubungan.

Selanjutnya penelitian Ulya, Irawati, \& Maulana (2016) mengungkapkan KKnM yang masih sangat rendah yang disebabkan oleh beberapa faktor, salah satu faktor penyebabnya adalah kegiatan pembelajaran yang dilaksanakan cenderung bersifat teacher-centered. Lebih jauh disampaikan karena terkadang terdapat hasil siswa yang membanggakan namun kurang dihargai.

Selanjutnya peneliti melakukan wawancara dengan salah seorang guru matematika SMP di Padangsidimpuan, diperoleh informasi bahwa dalam pembelajaran siswa merasa kesulitan menghubungkan materi yang telah diketahui terhadap pemecahan masalah, sulitnya pemahaman siswa terhadap materi pelajaran, ingatan siswa terhadap materi yang diajarkan tidak bertahan lama, siswa susah menerpakan konsep yang telah diterimanya dalam pemecahan masalah yang berdampak pada rendahnya hasil belajar siswa. Disampaikan juga pembelajaran yang dilakukan cenderung bersifat 


\section{JURNAL GANTANG. Oktober 2019; IV(2): 121 - 132 \\ p-ISSN. 2503-0671 \\ e-ISSN. 2548-5547}

konvensional dan siswa cenderung belajar melalui hafalan terhadap konsep dan materi pelajaran. Dengan demikian dapat disimpulkan bahwa KKnM siswa rendah, pembelajaran masih bersifat konvensional.

Menyikapi rendahnya KKnM siswa dan penerapan pembelajaran yang kurang sesuai dengan materi pelajaran perlu dilakukan penerapan pembelajaran yang melibatkan siswa aktif dalam pembelajaran atau pembelajaran yang bersifat student centred. Ahmad \& Nasution (2018) mengungkapkan bahwa untuk mencapai kemampuan bermatematika yang baik, seorang pendidik hendaknya dapat menciptakan suasana belajar yang menyenangkan dan memungkinkan bagi siswa sebagai peserta didik untuk aktif dalam kegiatan pembelajaran dengan mengkonstruksi, menemukan dan mengembangkan pengetahuannya. Pembelajaran yang terlaksana didalam kelas perlu didesain sedemikian rupa agar siswa dapat aktif menemukan dan memecahkan masalah dengan maksimal yang pada akhirnya mampu membuat jawaban dengan baik dan benar dan membuahkan hasil yang memuaskan.

Pendekatan open-ended dalam pelaksanaannya dilakukan melalui kegiatan membahas dan memecahkan masalah. Masalah yang digunakan dalam pembelajaran dengan pendekatan open-ended berbasis pada masalah terbuka. Soal open-ended adalah soal yang memberikan peluang kepada siswa untuk memberikan jawaban terhadap persoalan dengan berbagai macam jawaban atau cara penyelesaian yang baik dan benar (Ekowati \& Guntoro, 2008). Masalah terbuka yang dimaksud dalam hal ini ada dua macam yaitu masalah yang pemecahannya memiliki hasil akhir yang lebih dari satu jawaban dan masalah yang pemecahannya dilakukan dengan menggunakan metode/ teknik lebih dari satu cara.

Pemecahan terhadap permasalahan yang bersifat terbuka membutuhkan proses berpikir yang komplit dan sistematis, yaitu dalam memunculkan alternatif-alternatif jawaban dengan berbagai cara sehinnga dapat menuju suatu jawaban benar dari masalah yang diberikan (Usman, 2006). Dengan demikian masalah terbuka yang disajikan pada siswa bertujuan untuk melatih dan mengembangkan kemampuan siswa untuk berpikir secara sistematis serta mampu memecahkan berbagai permalasahan yang dihadapinya.

Dalam membuat masalah open-ended Becker \& Shimada mengungkapkan beberapa hal penting yang dapat dijadikan sebagai acuan, yaitu: (1) Memberikan permasalahan melalui situasi fisik yang nyata; 2) Soal-soal pembuktian dapat diubah sedemikian rupa sehingga siswa dapat menemukan hubungan dan sifat-sifat dari variabel; 3) Menyajikan bangun-bangun geometri sehingga siswa dapat membuat suatu konjektur; 4) Memberikan suatu barisan bilangan sehingga siswa dapat menemukan aturan matematika; 5) Menyajikan contoh nyata dalam beberapa kategori sehingga siswa dapat mengelaborasi sifat-sifat dari contoh itu untuk menemukan sifatsifat yang bersifat umum (Sariningsih \& Herdiman, 2017).

Penerapan pembelajaran dengan pendekatan open-ended dalam mengajarkan kemampuan bematematika siwa, Suherman et al., (2001) mengungkapkan terdapat tiga aspek yang harus dipenuhi antara lain: 1) Kegiatan siswa harus terbuka yaitu kegiatan pembelajaran harus mengakomodasi kesempatan siswa untuk melaksanakan sesuatu secara bebas sesuai kehendak mereka; 2) Kegiatan matematika adalah ragam pikiran yaitu dalam kegiatan matematika terjadi proses pengabstraksian dari pengalaman nyata yang bersumber dari kehidupan dunia nyata/ kehidupan sehari-hari kedalam matematika formal atau sebaliknya; 3) Aktivitas siswa dalam matematika merupakan satu kesatuan yang tidak terpisahkan yaitu pemahaman siswa dalam memecahkan masalah, perluasan dari konsep/materi yang dipahami dan pendalaman berpikir matematika sesuai dengan kemampuan individu.

Pembelajaran dengan pendekatan openended menjadikan guru berperan sebagai motivator dan fasilitator terhadap peserta didik 
baik langsung kepada individu siswa maupun kelompok belajar siswa. Masalah yang diberikan dalam pembelajaran merupakan masalah terbuka yang dapat disajikan dalam lembar aktivitas siswa (LAS). LAS merupakan media pembelajaran yang disusun berdasarkan target yang ingin dicapai dalam tiap pertemuan kegiatan pembelajaran. Kegiatan pembelajaran dilaksanakan oleh guru dan siswa guna mencapai mencapai tujuan tertentu (Ahmad, Siregar, Siregar, \& Effendi, 2018).

Penerapan pembelajaran dengan pendekatan open-ended dalam tahapan pelaksanaan penelitian dilakukan dengan langkah berikut: 1) Membentuk kelompok belajar siswa, dengan masing-masing kelompok siswa memiliki kemampuan yang heterogen yang beranggotakan 4-6 orang; 2) Menyajikan masalah masalah terbuka kepada siswa, sehingga siswa memiliki kesempatan untuk melakukan eksplorasi terhadap materi pelajaran melalui pemecahan masalah dengan baragam cara-atau beragam jawaban; 3) Mempersilahkan siswa untuk memecahkan permasalahan dan memberi bantuan (scaffolding) pada kelompok yang mengalami kesulitan dalam memecahkan masalah; 4) Membimbing siswa memperagakan hasil diskusi kelompok serta mendiskusikan dan membandingkan jawaban dari masing-masing kelompok yang dilakukan melalui membaca, menulis dan menjelaskan di depan kelas; 5) memimpin dan mengarahkan siswa untuk membuat simpulan dari materi yang dipelajari.

Berbagai penelitian dengan menerapkan pendekatan open-ended menunjukakan hasil yang memuaskan dalam membelajarkan kemampuan bermatematika siswa. Penelitian tersebut anra lain penelitian Dewi (2018) menunjukkan bahwa: (1) Melalui pembelajaran dengan pendekatan openended lebih dari $50 \%$ siswa mencapai ketuntasan dalam belajar, dan (2) Nilai rata-rata kemampuan pemecahan masalah matematika siswa pada pembelajaran dengan pendekatan open-ended lebih tinggi dari pada pembelajaran dengan pendekatan konvensional dan memberi simpulan bahwa penerapan pendekatan open-ended efektif ditinjau dari kemampuan pemecahan masalah matematis siswa.
Husniah, Maulana, \& Isrok'atun (2017) mengungkapkan bahwa pendekatan open-ended memberi pengaruh positif terhadap kemampuan pemecahan masalah matematika yang ditandai dengan adanya peningkatan kemampuan pemecahan masalah matematis siswa di kelas eksperimen dengan kategori sedang, selanjutnya penerapan pendekatan open-ended lebih baik daripada pendekatan konvensional dalam meningkatkan kemampuan pemecahan masalah matematika siswa.

Penelitian Adirakasiwi

mengungkapkan perolehan peningkatan KKnM siswa melalui pembelajaran pendekatan openended lebih baik daripada $\mathrm{KKnM}$ siswa yang diberi pembelajaran dengan pendekatan konvensional dan disampaikan juga bahwa terdapat asosiasi antara $\mathrm{KKnM}$ dengan kemandirian belajar dengan kategori sangat tinggi. Dari uraian sebelumnya peneliti tertarik melakukan penelitian terhadap peningkatan KKnM siswa melalui penerapan pembelajaran matematika dengan pendekatan open-ended pada siswa kelas VII SMP Negeri 5 Padangsidimpuan.

\section{Metode Penelitian}

Penelitian ini merupakan penelitian kuasi eksperimen yang bertujuan untuk mendeskripsikan peningkatan KKnM siswa melalui pembelajaran dengan pendekatan openended. Untuk mencapai tujuan tersebut dilakukan penelitian dengan rancangan Nonequivalent control group design. Sugiyono (2016) mengungkapkan rancangan penelitian nonequivalent control group design hampir sama dengan pretest-posttest control group design hanya saja untuk pemilihan sampel pada kelas eksperimen atau kelas kontrol tidak dilakukan pemilihan secara acak. Dengan adanya kelas eksperimen dan kelas kontrol maka peningkatan KKnM siswa yang diberi pembelajaran dengan pendekatan open-ended lebih jelas karena dapat dibandingkan dengan KKnM siswa dari pendekatan konvensional atau pendekatan yang biasa dilakukan pada sekolah tempat penelitian.

Pupulasi penelitian adalah siswa kelas VII SMP Negeri 5 Padangsidimpuan sebanyak 9 ruangan belajar. Selanjutnya dipilih sampel 


\section{JURNAL GANTANG. Oktober 2019; IV(2): 121 - 132 \\ p-ISSN. 2503-0671 \\ e-ISSN. 2548-5547}

penelitian sebanyak dua kelas yang dijadikan sebagai kelas eksperimen dan kelas kontrol. Kelas eksperimen adalah kelas VII-5 dengan jumlah siswa 28 orang dan kelas kontrol adalah kelas VII6 dengan jumlah siswa 28 orang. Adapun rancangan penelitian yang digunakan dalam penelitian ini adalah sebagai berikut:

Tabel 1.

Desain ekseperimen

\begin{tabular}{|lll|}
\hline $0_{1}$ & $\mathrm{X}$ & $0_{2}$ \\
\hline $0_{3}$ & & $0_{4}$ \\
\hline
\end{tabular}

Keterangan:

$0_{1}$ : Pretest KKnM siswa kelas eksperimen

$\mathrm{O}_{2}$ : Posttest $\mathrm{KKnM}$ siswa kelas eksperimen

$0_{3}$ : Pretest KKnM siswa kelas kontrol

$0_{4}$ : Posttest KKnM siswa kelas kontrol

$\mathrm{X}$ : Perlakuan pendekatan open-ended

Instrumen atau alat pengumpul data yang digunakan dalam penelitian ini adalah instrumen tes. Tes yang digunakan dalam penelitian adalah instrumen yang telah memenuhi validasi oleh pakar dan uji-coba lapangan. Validasi pakar dilakukan oleh validator yang berkompeten dalam penerapan pembelajaran matematika dengan pendekatan open-ended dan KKnM siswa. Validasi dilakukan terhadap butir soal pretest dan posttest yang masing-masing 7 butir soal.

Berdasarkan hasil analisis validator terhadap validasi isi dan bahasa soal diperoleh simpulan bahwa 5 soal tanpa revisi dan 2 soal revisi kecil. Setelah revisi instrumen berdasarkan saran dari validator dilakukan ujicoba lapangan. Ujicoba lapangan bertujuan untuk mendapatkan tingkat validitas dan reliabilitas dari instrumen yang akan dijadikan sebagai alat pengumpul data. Instrumen dapat digunakan sebagai alat pengumpul data dalam penelitian setidaktidaknya memenuhi tingkat validitas dan reliabilitas (Arikunto, 2009).

Berdasarkan ujicoba lapangan terhadap instrumen butir soal pretest dan posttest diperoleh nilai indeks korelasi $\left(\mathrm{r}_{\mathrm{xy}}\right)$ pada tebel 1 berikut.
Tabel 2.

Indeks korelasi butir tes

\begin{tabular}{ccccc}
\hline \multirow{2}{*}{$\begin{array}{c}\text { Noal } \\
\text { Soal }\end{array}$} & \multicolumn{2}{c}{ Pretest } & \multicolumn{2}{c}{ Posttest } \\
\cline { 2 - 5 } & $\mathbf{r}_{\mathbf{x y}}$ & Interpretasi & $\mathbf{r}_{\mathbf{x y}}$ & Interpretasi \\
\hline 1 & $0,58^{* *}$ & Sedang & $0,67^{* *}$ & Sedang \\
\hline 2 & $0,47^{*}$ & Sedang & $0,50^{*}$ & Sedang \\
\hline 3 & $0,47^{*}$ & Sedang & $0,45^{*}$ & Sedang \\
\hline 4 & 0,04 & $\begin{array}{c}\text { Sangat } \\
\text { Rendah }\end{array}$ & 0,20 & Rendah \\
\hline 5 & $0,43^{*}$ & Rendah & 0,20 & Rendah \\
\hline 6 & $0,67^{* *}$ & Sedang & $0,74^{* *}$ & Sedang \\
\hline 7 & $0,58^{* *}$ & Sedang & $0,56^{* *}$ & Sedang \\
\hline
\end{tabular}

Dari hasil indeks korelasi maka soal pretest no. 1,2,3,6 dan 7 dapat memenuhi validasi butir soal selanjutnya diperoleh indeks reliabilitas sebesar 0,486 berada pada kategori sedang. Berdasarkan hasil posttes diperoleh indeks korelasi sebagaimana terdapat pada tabel 1 maka butir soal posttest no. 1,2,3,6 dan 7 memenuhi validasi butir soal dan selanjutnya diperoleh indeks reliabilitas sebesar 0,443 berada pada kategori sedang.

Pengumpulan data dilakukan melalui pemberian pretest dan posttest pada siswa di kelas eksperimen dan kelas kontrol. Soal pretest dan soal posttest yang diberikan adalah soal yang memenuhi validitas dan reliabilitas yang masingmasing sebanyak 5 soal. Pretest dilakukan kepada siswa sebelum melaksanakan pembelajaran dan posttest dilakukan setelah pembelajaran 4 kali pertemuan melalui pembelajaran dengan pendektan open-ended yang dilaksanakan. Untuk tiap pertemuannya dilakukan pembelajaran dengan alokasi waktu 80 menit $(2 \times 40$ "). Materi yang diterapkan dalam pembelajaran disesuiakan dengan kurikulum SMP pada mata pelajaran matematika kelas VII semester genap tahun ajaran 2018/2019 yaitu materi bagun datar pada pokok bahasan persegi dan persegipanjang. Materi/ pokok bahasan yang digunakan dalam kegiatan pembelajaran adalah pengertian bangun datar persegi dan persegi panjang, sifat sifat, keliling dan luas, penerapan konsep persegi dan persegi panjang dalam pemecahan masalah.

Analisis data $\mathrm{KKnM}$ siswa dilakukan dengan membandingkan peningkatan ( $N$-gain score) $\mathrm{KKnM}$ siswa yang diperoleh dari kelas 
eksperimen dan kontrol dari tahapan pengumpulan data penelitian. Penentunan tingkat peningkatan $\mathrm{KKnM}$ siswa sebelummya harus memenuhi tingkat signifikansi melalui analisis statistik uji Independent samples test untuk menentukan sigifikansi apakah terdapat perbedaan hasil pretest dan posttest kelas eksperimen dan kelas kontrol. Untuk melakukan uji tersebut terlebih dahulu dilakukan uji normalitas untuk menganalisis kenormalan varian data dan uji homogenitas untuk menganalisis homogenitas varian data.

\section{Hasil dan Pembahasan}

Penelitian dalam rangka menganalisis Kemampuan Koneksi Matematis (KKnM) siswa diawali dengan pemberian pretest kepada kelas eksperimen dan kelas kontrol, kemudian dilanjutkan dengan pembelajaran sebanyak 4 kali pertemuan dan diakhiri dengan posttest. Untuk mendapatkan tingkat peningkatan $\mathrm{KKnM}$ siswa dilakukan analisis $N$-gain score. Sebelum menganalisi $N$-gain harus memenuhi uji signifikansi melalui uji statistik independent samples test yang tentunya harus memenuhi uji prasyarat uji homogenitas dan normalitas varian data. Berikut dibawah ini hasil analisis tentang hasil Signifikansi uji homogenitas data pretest dan posttes pada kelas eksperimen dan kelas kontrol dengan uji Levene Statistic.

Tabel 3.

Indeks signifikansi normalitas

\begin{tabular}{lcc}
\hline \multicolumn{1}{c}{ Kelas } & Sig. & Keterangan \\
\hline Pretest & 0,599 & $>0,05$ \\
\hline Posttest & 0,720 & $>0,05$ \\
\hline
\end{tabular}

Berdasarkan perolehan data signifikansi dari uji homogenitas data pretest $\mathrm{KKnM}$ siswa pada kelas eksperimen dan kelas kontrol nilai sig. $0,599>0,05$ dapat disimpulkan bahwa data pretest $\mathrm{KKnM}$ siswa berdasarkan nilai pretest dari kelas eksperimen dan kelas kontrol mempunyai varian yang sama atau homogen, begitu juga dengan data posttest $\mathrm{KKnM}$ siswa nilai sig. 0,720 >0,05 dapat disimpulkan juga bahwa data posttest KKnM siswa berdasarkan nilai posttest kelas eksperimen dan kelas kontrol mempunyai varian yang sama atau homogen. Selanjutnya dari analisis normalitas dengan uji statistik One-Sample Kolmogorov-Smirnov Test diperoleh hasil sebagai berikut.

Tabel 4.

Indeks signifikansi homogenitas tes KKnM

\begin{tabular}{lcc}
\hline \multicolumn{1}{c}{ KKnM Siswa } & $\begin{array}{c}\text { Asymp. } \\
\text { Sig. (2- } \\
\text { tailed) }\end{array}$ & Keterangan \\
\hline Pretest Eksperimen & 0,500 & $>0,05$ \\
\hline Posttest Eksperimen & 0,281 & $>0,05$ \\
\hline Pretest Kontrol & 0,401 & $>0,05$ \\
\hline Posttest Kontrol & 0,259 & $>0,05$ \\
\hline
\end{tabular}

Dengan memperhatikan tabel 3 dapat diamati bahwa nilai Asymp. Sig. (2-tailed) pada pretest dan posttest $\mathrm{KKnM}$ siswa pada kelas eksperimen dan kelas kontrol berada diatas 0,05 maka dengan demikan distribusi data pretest dan posttest $\mathrm{KKnM}$ siswa pada kelas eksperimen dan kelas kontrol adalah berdistribusi normal.

Selanjutnya analisis deskriptif $\mathrm{KKnM}$ siswa diperoleh nilai rata-rata pada kelas eksperimen adalah 65,54 dan pada kelas kontrol adalah 65,36 pada posttest kelas eksperimen adalah 81,61 dan pada kelas kontrol adalah 74,46. Selanjutnya perbedaan peningkatan KKnM siswa pada kelas eksperimen dan kelas kontrol dianalisis dengan analisis statistik independent sampel t-test. Hasil analisis tersebut dapat dilihat pada tabel berikut.

Tabel 5 .

Analisis independent samples test

\begin{tabular}{|c|c|c|c|}
\hline \multicolumn{2}{|c|}{$\begin{array}{c}\text { Kemampuan Koneksi } \\
\text { Matematis }(\mathrm{KKnM}) \text { Siswa }\end{array}$} & $\begin{array}{c}\text { Equal } \\
\text { variances } \\
\text { assumed }\end{array}$ & $\begin{array}{c}\text { Equal } \\
\text { variances } \\
\text { not } \\
\text { assumed }\end{array}$ \\
\hline \multirow{2}{*}{$\begin{array}{c}\text { Levene's Test } \\
\text { for Equality of } \\
\text { Variances } \\
\end{array}$} & $\mathrm{F}$ & 0,130 & - \\
\hline & Sig. & 0,720 & - \\
\hline \multirow{3}{*}{$\begin{array}{c}\text { t-test for } \\
\text { Equality of } \\
\text { Means }\end{array}$} & $\mathrm{t}$ & 2,988 & 2,988 \\
\hline & $\mathrm{df}$ & 54 & 53,867 \\
\hline & Sig. (2-tailed) & 0,004 & 0,004 \\
\hline
\end{tabular}

Berdasarkan analisis uji statistik dengan Independent Samples Test diperoleh sig. (2tailed) adalah $0,003<0,05$ dan $t_{\text {hitung }}=2,988>$ dari $\mathrm{t}_{\text {tabel }}=1,684$ maka $\mathrm{H}_{0}$ ditolak dengan demikian disimpulkan bahwa terdapat perbedaan yang 


\section{JURNAL GANTANG. Oktober 2019; IV(2): 121 - 132 \\ p-ISSN. 2503-0671 \\ e-ISSN. 2548-5547}

signifikan (nyata) antara rata-rata hasil belajar siswa dari kelas eksperimen dan kelas kontrol. Selanjutnya berdasarkan analisis perolehan data KKnM siswa Pretest dan Posttest pada kelas Eksperimen dan kelas kontrol maka nilai $\mathrm{N}$-gain dapat diamati pada tabel berikut.

Tabel 6.

Indeks $N$-gain

\begin{tabular}{lcc}
\hline \multicolumn{1}{c}{ Kelas } & Eskperimen & Kontrol \\
\hline$N$-gain & 0,48 & 0,28 \\
\hline Interpretasi & Sedang & Rendah \\
\hline
\end{tabular}

Perolehan nilai $\mathrm{N}$-gain kelas Eksperimen adalah sebesar 0,48. Nilai ini berada dalam kategori sedang. Selanjutnya nilai $N$-gain pada kelas kontrol adalah sebesar 0,28. Nilai ini berada dalam kategori rendah. Dengan memperhatikan nilai $N$-gain pada kelas eksperimen dan kelas kontrol maka $N$-gain pada kelas eksperimen lebih besar dari pada $\mathrm{N}$-gain kelas kontrol dengan kata lain $N$-gain pada kelas eksperimen lebih baik daripada $\mathrm{N}$-gain kelas kontrol. Dengan demikian dinyatakan bahwa peningkatan KKnM siswa pada kelas eksperimen lebih baik daripada kelas kontrol. Diagram perolehan $\mathrm{N}$-gain dapat diamati pada bagan berikut.

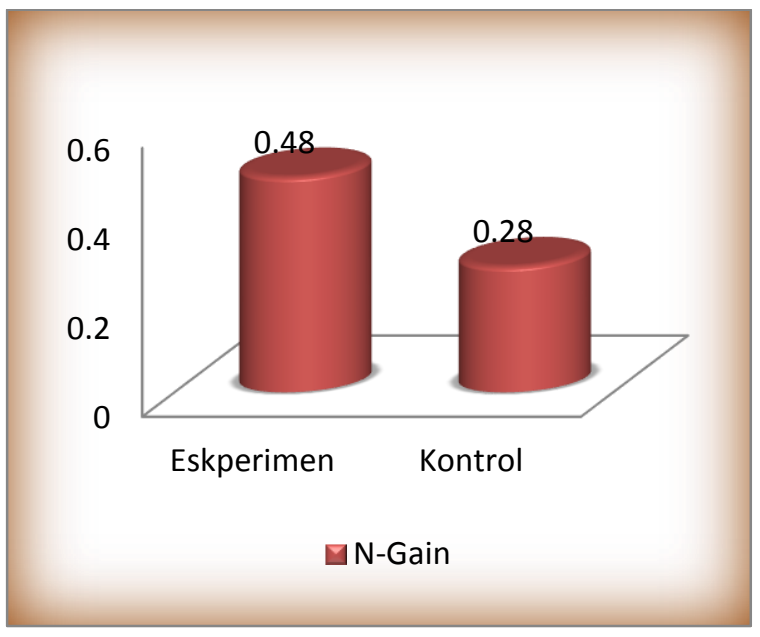

Gambar 1. Capaian N-gain Score

Data KKnM diperoleh melalui pemberian tes terhadap siswa. Tes tersebut diberikan kepada siswa kelas eksperimen dan kelas kontrol, sebelum perlakuan (pretest) dan setelah perlakuan (posttest). Data dari pretest dan posttest ini selanjutnya dihitung nilai normalitas dan homogenitasnya. Berdasarkan temuan bahwa data berdistribusi normal dan homogen maka dilanjutkan dengan uji independen sampel t-tes. Berdasarkan uji statistik yang dilakukan diperoleh simpulan bahwa terdapat perbedaan yang signifikan (nyata) antara rata-rata $\mathrm{KKnM}$ siswa dari kelas yang diberi pembelajaran dengan pendekatan kontekstual dan kelas yang diberi pembelajaran dengan pendekatan konvensional. Hal senada juga diungkapkan dalam penelitian Gordah (2012) bahwa pembelajaran melalui pendekatan open-ended dapat meningkatkan KKnM dan pemecahan masalah matematis peserta didik yang lebih baik daripada pembelajaran konvensional.

Meskipun terdapat peningkatan yang signifikan terhadap $\mathrm{KKnM}$ siswa, namun peningkatan yang terjadi pada kelas kontrol lebih rendah dan belum menjadikan siswa memiliki KKnM seperti yang diharapkan. Hal ini disebabkan siswa masih kesulitan dalam mengkoneksikan konsep dan ide matematika dalam permasalahan kehidupan sehari-hari. Selain itu, dalam kegiatan pembelajaran siswa cenderung memperhatikan penjelasan guru ketika memberikan contoh dalam proses pembelajaran. Pembelajaran yang terlaksana cenderung bersifat konvensional ditandai dengan pembelajaran didominasi oleh aktivitas guru proses pembelajaran (Ahmad \& Asmaidah, 2017). Disisi lain, kontribusi pendekatan open-ended tersebut menunjukkan bahwa open-ended lebih unggul dibandingkan dengan pembelajaran dengan pendekatan konvensional.

Selanjutnya jika ditinjau dari jawaban siswa dari kelas eksperimen atau siswa yang diberi pembelajaran dengan pendekatan openended terhadap soal yang diujikan dapat dilihat bahwa siswa mampu dalam kemampuan koneksi matematika dalam memecahkan permasalahan. Salah satu soal yang diujikan pada posttest adalah terkait dengan menentukan biaya pemasangan pagar disekeliling kebun Pak Tahan. Soal tersebut yaitu "Pak Tahan mempunyai sebidang kebun 
berbentuk persegi panjang dengan ukuran panjang 10 meter dan lebar 7 meter. Jika di sekeliling kebun tersebut dipasang pagar kawat dengan biaya Rp. 75.000,- per-meter. Tentukan biaya pemasangan pagar kawat kebun Pak Tahan!'. Berikut dibawah ini disajikan jawaban siswa terhadap soal (no.5) posttest tersebut.

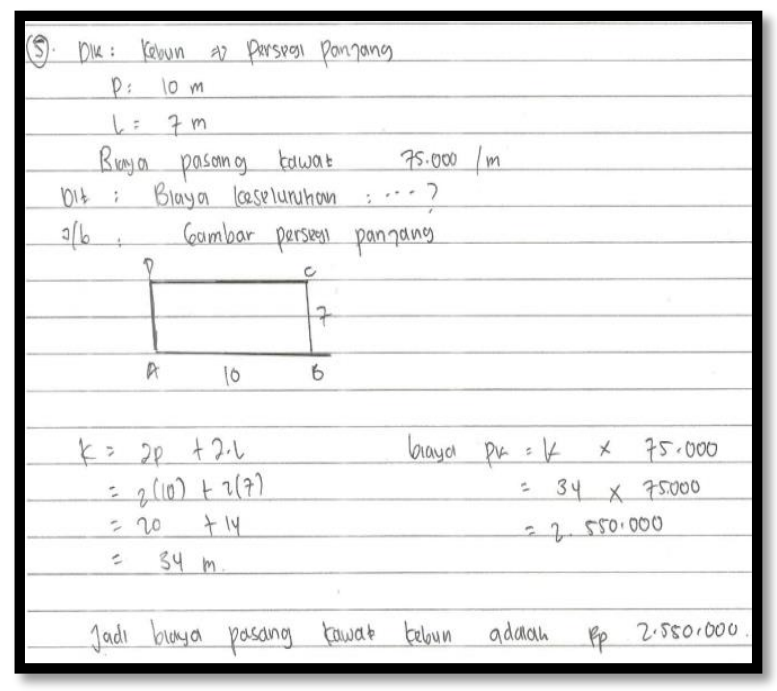

Gambar 2. Jawaban soal no.5 oleh siswa-1

Dari penyelesaian siswa terhadap soal no.5 diatas tampak bahwa siswa memberikan jawaban dengan baik dan benar. Jawaban diawali siswa dengan menuliskan yang dipahami dari soal yang meliputi diketahui dan ditanya. Dalam membuat yang diketahui siswa memahami bentuk kebun pak Tahan adalah persegipanjang. Serta siswa bisa membuat ide matematika $p=10 \mathrm{~m}$ dan $l=7 m$. Dari hal tersebut siswa menghubungkan permasalahan sehari-hari kedalam ide matematika. Selanjutnya siswa membuat sketsa kebun dengan bentuk persegipanjang $\mathrm{ABCD}$ dan membuat rumus keliling persegipanjang yaitu $K=2 p+2 l$. Dalam hal ini siswa menghubungkan antar konsep matematika.

Selanjutnya siswa melanjutkan dengan perhitungan keliling persegipanjang dan melanjutkannya dengan menentukan besar biaya yang diperlukan dalam membuat pagar kawat disekeliling kebun. Dalam hal ini siswa menghubungkan ide-ide matematika dalam memecahkan permasalahan. Selanjutnya siswa lain juga memberikan hasil akhir jawaban soal yang sama dengan cara pemecahan sebagai berikut.

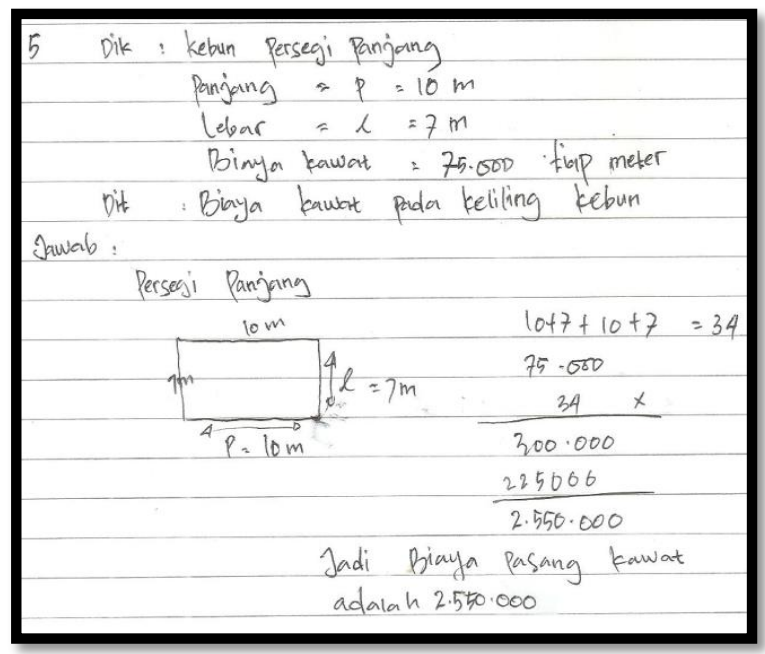

Gambar 3. Jawaban soal no.5 oleh siswa-2

Selanjutnya dari jawaban siswa-2 untuk no.5 dapat diamati bahwa kemampuan koneksi matematika siswa adalah baik. Dimana siswa mampu menuliskan permasalahan kedalam model matematika yaitu dengan menentukan panjang dan lebar persegipanjang. Dengan demikian siswa menghubungkan situasi terhadap konsep matematika. Selanjutnya siswa menggambarkan sketsa kebun dalam berbentuk persegipanjang dengan panjang 10 meter dan lebar 7 meter. Selanjutnya siswa menentukan keliling dari kebun (persegipanjang) dengan menjumlahkan sisi-sisi persegipanjang yaitu $10+7+10+7=34$. Dari perhitungan itu tentu siswa mengunakan konsep menghitung keliling dengan menjumlahkan $2 p$ dan $2 l$ dengan cara $p+l+$ $p+l=2 p+2 l=K . \quad$ Hal ini siswa menghubungkan keterkaitan ide-ide matematika. Selanjutnya siswa mengalikan nilai keliling $(K)$ persegipanjang dengan biaya pemasangan kawat tiap meternya yaitu dengan mengalikan 34 dengan 75.000,-. Melalui proses hitung perkalian bilangan diperoleh hasil 2.550.000. Selanjutnya diakhiri siswa dengan memberikan kesimpulan. Dengan demikian siswa mampu mengkaitkan konsep-konsep matematika dalam memecahkan permasalahan sehari-hari.

Jawaban yang diberikan kedua siswa terhadap soal posttest no. 5 memberikan hasil yang benar. Dari jawaban tersebut tampak bahwa 


\section{JURNAL GANTANG. Oktober 2019; IV(2): 121 - 132 \\ p-ISSN. 2503-0671 \\ e-ISSN. 2548-5547}

siswa mampu dalam memahami dan menerapkan hubungan antar berbagai konsep matematika, menerapkan konsep matematika dalam suatu permasalahan dan menerapkan konsep matematika dalam memecahkan permasalahan sehari-hari dengan katalain kemampuan koneksi matematika siswa baik.

Ditinjau dari nilai indeks gain (peningkatan) $\mathrm{KKnM}$ siswa yang diberi pembelajaran dengan pendekatan open-ended pada kelas eksperimen lebih baik dari pada siswa yang diberi pembelajaran dengan pendekatan konvensional pada kelas kontrol. Perolehan nilai rata-rata Ngain $\mathrm{KKnM}$ siswa kelas eksperimen adalah sebesar 0,48 (sedang) dan dan pada kelas kontrol adalah sebesar 0,28 (Rendah). Hal ini dikarenakan dalam pembelajaran open-ended siswa terbiasa memecahkan masalah dengan bervariasi sehingga konsep yang dipahami siswa lebih kaya. Selain itu siswa fleksibel/luwes dalam memberikan jawaban terhadap suatu soal. Hal ini terlihat dari pembahasan siswa terhadap salahsatu soal posttest yang diujikan.

Hal serupa juga ditemukan peneliti sebelumnya yaitu Sari (2015) melalui nilai ratarata $N$-gain ternormalisasi ditunjukkan bahwa hasil peningkatan $\mathrm{KKnM}$ siswa melalui pembelajaran open-ended $(N$-gain $=0,257)$ lebih tiggi dari pada pembelajaran biasa $(N$-gain $=$ 0,201). Selanjutnya Muchlis et al., (2018) mengungkapkan bahwa melalui hasil penelitian dan pengolahan data $\mathrm{KKnM}$ siswa diperoleh bahwa pembelajaran melalui pendekatan openended dengan setting model pembelajaran kooperatif tipe NHT lebih baik dari pada KKnM siswa yang pembelajarannya menggunakan pendekatan konvensional, dengan kata lain, secara signifikan KKnM pada kelompok eksperimen lebih baik peningkatannya daripada kelompok kontrol. Terjadinya perbedaan peningkatan KKnM ini disebabkan adanya penggunaan pendekatan open-ended pada kelas eksperimen. Pembelajaran dengan pendekatan open-ended mendorong siswa untuk lebih mengembangkan kreativitasnya dalam mengoneksikan antara konsep matematika, konsep matematika dengan ilmu lain dan konsep matematika dengan kehidupan sehari-hari. Hal ini dikarenakan (Lambertus, Arapu, \& Patih, 2013) proses pembelajaran dengan pendekatan openended lebih menekankan pada peran aktif siswa untuk menemukan berbagai cara penyelesaian masalah matematika.

\section{Kesimpulan}

Penelitian yang dilakukan untuk menganalisis tentang peningkatan Kemampuan Koneksi Matematis (KKnM) siswa melalai pembelajaran dengan pendekatan open-ended disimpulkan bahwa secara signifikan KKnM siswa yang diberi pembelajaran dengan pendekatan open-ended berbeda dengan $\mathrm{KKnM}$ siswa yang diberi pembelajaran dengan pendekatan konvensional. Peningkatan KKnM siswa melalui pendekatan open-ended memiliki nilai $N$-gain 0,43 berada dalam kategori sedang lebih baik dari pada peningkatan KKnM siswa dengan pendekatan kontekstual yang memiliki nilai $N$-gain 0,28 berada dalam kategori rendah.

Pembelajaran matematika melalui pendekatan open-ended terlaksana dengan mengaktifkan siswa dalam pembelajaran sehingga siswa mampu menyelesaikan soal dengan beragam dan konsep yang dipahami siswa lebih kaya. Selanjutnya pada pembelajaran dengan pendekatan konvensional siswa cenderung memahami contoh soal yang diberikan lalu mengikutinya untuk memecahkan permasalahan. KKnM melalui pembelajaran dengan pendekatan open-ended lebih berkembang dari pada KKnM siswa melalui pembelajaran dengan pendekatan konvensional.

\section{Ucapan Terimakasih}

Artikel ini merupakan publikasi hasil penelitian dengan skema Penelitian Dosen Pemula (PDP) Bidang Fokus Sosial HumanioraSeni Budaya-Pendidikan tahun anggaran 2018 dengan pendanaan tahun 2019 menggunakan dana yang bersumber dari DRPM DIKTI. Oleh sebab itu penulis mengucapkan terimakasih kepada DRPM Kemenristekdikti yang telah memberikan dana dalam pelaksanaan penelitian ini. Terimakasih juga penulis sampaikan kepada 
pihak pimpinan dan guru SMP Negeri 5 Padangsidimpuan yang telah memberikan izin dan dukungan kepada penulis dalam melaksanakan penelitian.

\section{Referensi}

Adirakasiwi, A. G. (2018). Peningkatkan kemampuan koneksi matematis dan kemandirian belajar siswa melalui pendekatan open-ended. Aksioma, 7(2), 283-290.

https://doi.org/10.24127/ajpm.v7i2.1508

Ahmad, M., \& Asmaidah, S. (2017). Pengembangan perangkat pembelajaran matematika realistik untuk membelajarkan kemampuan pemecahan masalah matematika siswa SMP. Jurnal "Mosharafa," 6(3), 373-384. https://doi.org/10.31980/mosharafa.v6i3.32 6

Ahmad, M., \& Nasution, D. P. (2018). Analisis kualitatif kemampuan komunikasi matematis siswa yang diberi pembelajaran matematika realistik. Jurnal Gantang, III(2), 83-95. https://doi.org/10.31629/jg.v3i2.471

Ahmad, M., Siregar, Y. P., Siregar, N. A., \& Effendi, H. (2018). Realistic math-based learning model based on mandailing culture. International Journal of Sciences: Basic and Applied Research (IJSBAR), 39(1), 67-78. https://doi.org/10.17605/osf.io/4cp5y

Arikunto, S. (2009). Manajemen penelitian. Jakarta: Rineka Cipta.

Dewi, P. S. (2018). Efektivitas pendekatan open ended ditinjau dari kemampuan pemecahan masalah matematis. Prisma, VII(1), 11-19.

Ekowati, E., \& Guntoro, K. (2008). Peningkatan pembelajaran geometri dengan soal open ended menantang siswa berpikir tingkat tinggi. Pythagoras, 4(2), 1-13. https://doi.org/10.21831/pg.v4i2.51

Gordah, E. K. (2012). Upaya guru meningkatkan kemampuan koneksi dan pemecahan masalah matematis peserta didik melalui pendekatan open ended. Jurnal Pendidikan Dan Kebudayaan, 18(3), 264-279. http://dx.doi.org/10.24832\%2Fjpnk.v18i3.8

\section{7}

Hadi, S. (2017). Pendidikan matematika realistik: teori, pengembangan, dan implementasinya. Jakarta: Rajawali Pers.

Husniah, G. N., Maulana, M., \& Isrok'atun, I. (2017). Pengaruh pendekatan open-ended terhadap kemampuan pemecahan masalah matematis dan motivasi belajar. Jurnal Pena Ilmiah, 2(1), 841-850. https: //dx.doi.org/10.17509/jpi.v2i1.11220

Lambertus, Arapu, L., \& Patih, T. (2013). Penerapan pendekatan open-ended untuk meningkatkan kemampuan berpikir kreatif matematik siswa SMP. Jurnal Pendidikan Matematika, 4(1), 73-82.

Mendikbud. (2014). Peraturan Menteri Pendidikan dan Kebudayaan Republik Indonesia Nomor 58 tahun 2014 tentang Kurikulum 2013 Sekolah Menengah Pertama/ Madrasah Tsanawiyah. Retrieved from https: //drive.google.com/drive/folders/0ByHH9z o2NVq6fkdpWkZBR212bEE4TXdIdGUtV klvM19JRVp2NWRXZmQwWkprR3Jqdm g3ZXM

Muchlis, A., Komara, E. S., Kartiwi, W., Nurhayati, Hendriana, H., \& Hidayat, W. (2018). Meningkatkan koneksi matematis siswa smp melalui pendekatan open-ended dengan setting kooperatif tipe NHT. Kalamatika Jurnal Pendidikan Matematika, 3(1), 81-92.

NCTM. (2000). Principles and standards for school mathematics. Reston: VA NCTM. Retrieved from https://epdf.pub/queue/principles-andstandards-for-school-mathematics.html

Pitriani, R., \& Afriansyah, E. A. (2016). Persepsi dalam pembelajaran pendekatan keterampilan proses terhadap kemampuan koneksi matematis siswa (Studi penelitian di SMP Negeri 1 Wanraja). Jurnal Gantang, l(2), $15-24$. https://doi.org/10.31629/jg.v1i2.51

Purwaningrum, J. P. (2016). Kemampuan koneksi matematis siswa SD melalui Circuit Learning. $\quad J P S D, \quad 2(2), \quad 125-137$. http://dx.doi.org/10.30870/jpsd.v2i2.792 
JURNAL GANTANG. Oktober 2019; IV(2): 121 - 132

p-ISSN. 2503-0671

e-ISSN. 2548-5547

Puteri, J. W., \& Riwayati, S. (2017). Kemampuan koneksi matematis siswa pada model pembelajaran Conneted Mathematics Project (CMP). FIbonacci Jurnal Pendidikan Matematika Dan Matematika, $3(2)$, 161-168. https://doi.org/10.24853/fbc.3.2.161-168

Putra, R. A. C., \& Syarifuddin, A. (2019). Kemampuan koneksi matematis siswa tipe sensing-intuiting dalam menyelesaikan soal olimpiade. Jurnal Gantang, IV(1), 61-70. https://doi.org/10.31629/jg.v4i1.899

Sari, L. N. I. (2015). Peningkatan kemampuan koneksi matematis dan berpikir kreatif siswa melalui pembelajaran open ended di SMP Muhammadiyah 03 Padangsidimpuan. Logaritma, $\quad$ III(2), 70-83. http://dx.doi.org/10.24952/logaritma.v3i02. 1308

Sariningsih, R., \& Herdiman, I. (2017). Mengembangkan kemampuan penalaran statistik dan berpikir kreatif matematis mahasiswa melalui pendekatan open-ended. Jurnal Riset Pendidikan Matematika, 4(2), 239-246.

https://doi.org/10.21831/jrpm.v4i2.16685

Sugiman. (2008). Koneksi matematik dalam pembelajaran matematika dI Sekolah Menengah Pertama. Pythagoras, 4(1), 5667. https://doi.org/10.21831/pg.v4i1.687

Sugiyono. (2016). Metode Penelitian Kuantitatif, Kualitatif, Dan R\&D. Bandung: Alfabeta.

Suherman, E., Turmudi, Suryadi, D., Herman, T., Suhendra, Prabawanto, S., ... Rohayati, A. (2001). Strategi pembelajaran matematika kontemporer. Bandung: JICA-Universitas Pendidikan Indonesia (UPI).

Sumarmo, U. (2014). No Title. In Pengembangan hard skill dan soft skil matematiks bagi guru dan siswa untuk mendukung implementasi kurikulum 2013 (pp. 4-15). Prosiding Seminar Nasional Pendidikan Matematika ProgramPasca Sarjana STKIP Siliwangi Bandung.

Tasni, N., \& Susanti, E. (2017). Membangun

koneksi matematis siswa dalam pemecahan masalah verbal. Beta\urnal Tadris Matematika, $\quad 10(1), \quad 103-116$. http://dx.doi.org/10.20414/betajtm.v10i1.10 8

Ulya, I. F., Irawati, R., \& Maulana. (2016). Peningkatan kemampuan koneksi matematis dan motivasi belajar siswa menggunakan pendekatan kontekstual. Jurnal Pena Ilmiah, 1(1), 121-130. http://dx.doi.org/10.23819/pi.v1i1.2940

Usman. (2006). Aktivitas metakognisi mahasiswa calon guru matematika dalam pemecahan masalah terbuka. Jurnal Didaktik Matematika, $\quad 1(2), \quad 21-29$. https://doi.org/10.24815/jdm.v1i2.2058 